\title{
SUMBANGAN KOORDINASI MATA-KAKI, KELINCAHAN, KESEIMBANGAN DINAMIS DAN FLEKSIBILITAS TOGOK TERHADAP KEMAMPUAN MENGGIRING BOLA PADA PERMAINAN SEPAK BOLA
}

(Studi Korelasional pada Pemain Sepak Bola Mahasiswa Universitas Nusantara PGRI Kediri)

\author{
Andika Priya Pratama ${ }^{1}$, Sugiyanto Sugiyanto ${ }^{2}$, Agus Kristiyanto ${ }^{3}$ \\ ${ }_{1,2,3}$ Program Studi IImu Keolahragaan Program Pascasarjana \\ Universitas Sebelas Maret Surakarta \\ E-mail: andikapriyapratamaa@gmail.com ${ }^{1}$,aguskriss@yahoo.com ${ }^{3}$ \\ Diterima: 10 Desember 2017; Lolos: 27 April 2018; Dipublikasikan: 4 Mei 2018 \\ DOI: https://doi.org/10.29407/js_unpgri.v4i1.11747
}

\begin{abstract}
Abstrak
Tujuan penelitian ini untuk mengetahui seberapa berartinya sumbangan masingmasing variabel bebas (koordinasi mata-kaki, kelincahan, keseimbangan dinamis dan fleksibilitas togok) terhadap kemampuan menggiring bola dan untuk mengetahui seberapa berartinya sumbangan variabel bebas secara bersamasama terhadap kemampuan menggiring bola. Penelitian ini mengunakan pendekatan kuantitatif deskriptif korelasional dengan rancangan analisis regresi. Sampel adalah pemain sepak bola mahasiswa Universitas Nusantara PGRI Kediri dengan jumlah 40 dari total populasi 60 . Teknik pengambilan sampel menggunakan simple random sampling. Teknik analisis data mengunakan analisis regresi dengan bantuan software SPSS versi 16. Hasil analisis data menunjukkan bahwa: (1) $X_{1}$ memberikan sumbangan yang signifikan terhadap $Y$ dengan $t_{\text {hitung }}=5,472>t_{\text {tabel }}=2,021$, (2) $X_{2}$ memberikan sumbangan yang signifikan terhadap $Y$ dengan $t_{\text {hitung }}=2,716>t_{\text {tabel }}=2,021$, (3) $X_{3}$ memberikan sumbangan yang signifikan terhadap $Y$ dengan $t_{\text {hitung }}=3,046>t_{\text {tabel }}=2,021$, (4) $\mathrm{X}_{4}$ memberikan sumbangan yang signifikan terhadap $\mathrm{Y}$ dengan $t_{\text {hitung }}=2,595>$ $t_{\text {tabel }}=2,021$. Pada penelitian ini disimpulkan bahwa variabel koordinasi mata-kaki memberikan kontribusi sebesar 29,5\%, variabel kelincahan sebesar 26,8\%, variabel keseimbangan dinamis sebesar $4,8 \%$, variabel fleksibilitas togok sebesar $5,8 \%$. Sedangkan seluruh variabel independen memberikan kontribusi sebesar 95,8 \% terhadap kemampuan menggiring bola.
\end{abstract}

Kata kunci: Koordinasi, kelincahan, keseimbangan, fleksibilitas, menggiring bola.

\section{THE CONTRIBUTION OF EYE-FOOT COORDINATION, AGILITY, DYNAMIC BALANCE, AND TORSO FLEXIBILITY TO DRIBBLING ABILITY IN FOOTBALL GAME}

Abstract
The The objective of research was to find out the significant contribution of
independent variables partially (eye-foot coordination, agility, dynamic balance,
$\begin{array}{ll}\text { Email : andikapriyapratamaa@gmail.com } & \text { C2018 UN PGRI Kediri } \\ \text { No Handphone : } 081217206119 & \text { p-ISSN: } 2548-7833 \\ & \text { e-ISSN: } 2477-3379\end{array}$


Andika Priya Pratama, Sugiyanto Sugiyanto, Agus Kristiyanto

Sumbangan Koordinasi Mata-Kaki, Kelincahan, Keseimbangan Dinamis dan Fleksibilitas Togok Terhadap Kemampuan Menggiring Bola pada Permainan Sepak Bola

(Studi Korelasional pada Pemain Sepak Bola Mahasiswa Universitas Nusantara PGRI Kediri)

and torso flexibility) to dribbling ability and the significant contribution of independent variables simultaneously to dribbling ability. This research employed a correlational descriptive quantitative approach with regression analysis design. The sample of research was student football players in Nusantara PGRI University of Kediri, consisting of 40 taken from total population 60 players. The sampling technique used was simple random sampling one. Technique of analyzing data used was regression analysis with SPSS version 16 software help. The result of data analysis showed that: (1) $X_{1}$ contributed significantly to $Y$ with $t_{\text {statistic }}=5.472>t_{\text {table }}=2.021$, (2) $X_{2}$ contributed significantly to $Y$ with $t_{\text {statistic }}$ $=2.716>t_{\text {table }}=2.021$, (3) $X_{3}$ contributed significantly to $Y$ with $t_{\text {statistic }}=3.046>$ $t_{\text {table }}=2.021$, (4) $X_{4}$ contributed significantly to $Y$ with $t_{\text {statistic }}=2.595>t_{\text {table }}=$ 2.021. From the result of research, it could be concluded that eye-foot coordination variable contributed by $29.5 \%$, agility variable by $26.8 \%$, dynamic balance variable by $4.8 \%$, and torsion flexibility variable by $5.8 \%$. Meanwhile, all of independent variables contributed to dribbling ability by $95.8 \%$.

Keywords: Coordination, agility, balance, flexibility, dribbling.

\section{PENDAHULUAN}

Sepak bola merupakan olahraga yang cukup memasyarakat dan digemari seluruh lapisan masyarakat dunia mulai dari anak-anak sampai orang tua. Sepak bola merupakan salah satu olahraga yang paling digemari. Hampir dipastikan masyarakat dunia mengenal olahraga sepak bola (Sadik, 2016). Seperti yang dikemukakan Tarigan (2001) bahwa, "Sepak bola merupakan permainan beregu yang paling populer di dunia dan bahkan telah menjadi permainan Nasional bagi setiap negara di Eropa, Amerika Selatan, Asia, Afrika dan bahkan pada saat ini permainan itu digemari di Amerika Serikat". Olahraga sepak bola sangat membutuhkan energi yang tinggi. Sepak bola merupakan salah satu cabang olahraga yang berlangsung dengan ritme yang sangat cepat. Gerakan yang dilakukan oleh pemain antara lain berlari, menendang, melompat dan sprint yang persentasenya cukup besar (Khuddus, 2017). "The skill of a footballer is determined by the sum of many qualities that provide a high level of endurance, coordination of movements, accuracy, operative thinking" (Sergey, Anatoly, Boris, Svyatoslav, \& Victoria, 2017)

Permainan sepak bola dimainkan oleh sebelas pemain dalam satu tim, yang terdiri dari penjaga gawang, pemain bertahan, pemain tengah, dan pemain penyerang. Sebelas pemain dalam satu tim memiliki tugas masing-masing, seperti penjaga gawang yang bertugas mengamankan 
Andika Priya Pratama, Sugiyanto Sugiyanto, Agus Kristiyanto

Sumbangan Koordinasi Mata-Kaki, Kelincahan, Keseimbangan Dinamis dan Fleksibilitas Togok

Terhadap Kemampuan Menggiring Bola pada Permainan Sepak Bola

(Studi Korelasional pada Pemain Sepak Bola Mahasiswa Universitas Nusantara PGRI Kediri)

gawangnya, pemain bertahan bertugas sebagai pengawal pemain penyerang tim lawan, pemain tengah bertugas mengalirkan bola yang ada di belakang untuk di distribusikan pada penyerang dan pemain penyerang bertujuan untuk mencetak gol ke gawang lawan.

Menurut Al-Hadiqie (2014) menyatakan bahwa,"Skill atau ketangkasan yang harus dikuasi dalam bermain sepak bola yaitu: passing atau operan, heading atau menyundul, dribbling atau menggiring bola, shooting/kicking atau tendangan, moves, trapping, receiving dan kontrol".

Teknik menggiring bola (dribbling) pada permainan sepak bola memiliki peran yang penting agar bola yang dikuasai tidak direbut dengan mudah oleh lawan. Kemampuan menggiring bola berperan untuk memperoleh kemenangan dalam suatu pertandingan sepak bola. Pada situasi tertentu teknik menggiring bola akan menjadi penentu jalannya suatu pertandingan sepak bola tanpa mengkesampingkan kerja sama dalam sebuah tim sepak bola.

Kondisi fisik merupakan unsur pendukung yang penting untuk menunjang penguasaan keterampilan teknik. "Physical condition is a necessary requirement in improving an athlete's performance, and may even be regarded as a basic necessity that cannot be postponed or negotiable" (Hanief, Puspodari, \& Sugito, 2017) yang memiliki arti "Kondisi fisik merupakan kebutuhan yang diperlukan dalam meningkatkan kinerja atlet, dan bahkan dapat dianggap sebagai kebutuhan dasar yang tidak dapat ditunda atau dinegosiasikan". Kondisi fisik adalah salah satu prasyarat yang sangat diperlukan dalam setiap usaha peningkatan prestasi seorang atlit, bahkan dapat dikatakan dasar landasan titik tolak suatu awalan olahraga prestasi (Pratama, 2015).

Hubungan kondisi fisik dan sepak bola dan juga teknik dribble juga di bahas oleh Scheunemann (2012), "Komponen kondisi fisik yang dimiliki pemain sepak bola adalah speed, strenght, endurance, flexibility, accuration, power, coordination, reaction, balance, agility". Dalam kemampuan menggiring bola (dribbling), komponen fisik yang menunjang 
Andika Priya Pratama, Sugiyanto Sugiyanto, Agus Kristiyanto

Sumbangan Koordinasi Mata-Kaki, Kelincahan, Keseimbangan Dinamis dan Fleksibilitas Togok

Terhadap Kemampuan Menggiring Bola pada Permainan Sepak Bola

(Studi Korelasional pada Pemain Sepak Bola Mahasiswa Universitas Nusantara PGRI Kediri)

yaitu koordinasi mata-kaki, kelincahan, keseimbangan dinamis dan fleksibilitas togok.

Koordinasi pada dasarnya merupakan kemampuan merangkaikan beberapa gerakan menjadi satu pola gerakan yang serasi dan harmonis. Koordinasi merupakan kemampuan biomotorik yang dalam beroperasinya melibatkan beberapa unsur kondisi fisik lainnya (Hanief, 2015) Koordinasi adalah kemampuan atlet untuk merangkaikan gerak menjadi satu gerakan yang utuh dan selaras. Sehingga dapat dikatakan bahwa koordinasi mata-kaki merupakan kemampuan merangkaikan gerakan antara mata dan kaki menjadi satu gerakan keseluruhan yang berkesinambungan. Koordinasi mata-kaki merupakan dasar untuk mencapai kemampuan menggiring bola yang tinggi dalam bermain sepak bola. Dalam dribble atau kemampuan menggiring bola terdapat gabungan beberapa gerakan yang harus dilakukan secara terpadu dan selaras. Untuk melakukan dribble secara sempurna diperlukan koordinasi matakaki yang baik.

Kelincahan adalah kemampuan untuk bergerak mengubah arah dan posisi dengan cepat dan tepat sehingga memberikan kemungkinan seseorang untuk melakukan gerakan ke arah yang berlawanan dan mengatasi situasi yang dihadapi lebih cepat tanpa kehilangan keseimbangan (Diputra, 2015). Pada cabang olahraga sepak bola terutama pada kemampuan menggiring bola kelincahan sangat dibutuhkan karena pemain sepak bola dituntut untuk dapat bergerak lebih cepat dari lawan dan berusaha menghindar dari sergapan pemain bertahan sehingga pemain tersebut dapat melapaskan diri dari kawalan lawan atau dapat mencari posisi dalam menyerang dengan cepat tanpa bisa diikuti oleh pemain tim lawan.

Keseimbangan berperan penting pada permainan sepak bola, dalam hal ini adalah kemampuan menggiring bola atau dribble. Gerakangerakan dribble yang bercirikan perpindahan tempat dari satu titik ke titik lain dan pada saat mendapat tekanan dari pemain lawan (body contact) maka pemain yang sedang menggiring bola harus tetap bisa 
Andika Priya Pratama, Sugiyanto Sugiyanto, Agus Kristiyanto

Sumbangan Koordinasi Mata-Kaki, Kelincahan, Keseimbangan Dinamis dan Fleksibilitas Togok Terhadap Kemampuan Menggiring Bola pada Permainan Sepak Bola

(Studi Korelasional pada Pemain Sepak Bola Mahasiswa Universitas Nusantara PGRI Kediri)

mempertahankan keseimbangan tubuhnya. Selain itu, keseimbangan yang baik menjadikan gerakan lebih efektif dan efisien. Kemendiknas (2010) menjelaskan, "Salah satu dasar dalam menggiring bola yaitu harus bisa berubah arah dan kecepatan dribble dengan sekonyong-konyong (changing speed and reaction)".

Fleksibilitas tubuh menunjang keterampilan bermain sepak bola. Pemain sepak bola dapat belajar teknik bermain sepak bola dengan hasil yang memuaskan jika memiliki tubuh yang lentur dan tidak kaku. Fleksibilitas juga bisa sangat menentukan apakah seseorang pemain sepak bola dapat menyelesaikan babak pertandingan. Selalu melakukan pemanasan kemudian melenturkan tubuh (streching) sebelum bermain sepak bola. Kombinasi kelentukan dan kekuatan akan menjadi alur gerak (fluidity) si pemain, mudah dan mengesankan latihan khususnya untuk meningkatkan kelenturan tubuh.

Pemain sepak bola yang memiliki kelentukan togok yang baik, akan dapat meliuk dan menghindar dengan baik pada saat menggiring bola pada permaian sepak bola untuk melewati lawan yang menghadang. Ini disebabkan, dengan fleksibilitas togok yang baik, maka pernain sepak bola akan dapat melakukan gerakan secara elastis dan luwes pada saat melakukan gerakan menggiring bola. Dengan demikian untuk mendapatkan keterampilan yang baik, maka pemain sepak bola harus memiliki fleksibilitas togok baik pula.

Koordinasi mata-kaki, kelincahan, keseimbangan dan fleksibilitas togok merupakan komponen kondisi fisik yang penting dalam pencapaian sebuah prestasi dalam olahraga. Namun, perlu dilakukan penelitian seberapa besar sumbangan koordinasi mata-kaki, kelincahan, keseimbangan dan fleksibilitas togok terhadap kemampuan menggiring bola dalam permainan sepak bola.

\section{METODE}

Penelitian ini menggunakan pendekatan kuantitatif deskriptif korelasional dengan rancangan analisis regresi. Populasi dalam penelitian ini adalah pemain sepak bola mahasiswa Universitas Nusantara PGRI 
Andika Priya Pratama, Sugiyanto Sugiyanto, Agus Kristiyanto

Sumbangan Koordinasi Mata-Kaki, Kelincahan, Keseimbangan Dinamis dan Fleksibilitas Togok

Terhadap Kemampuan Menggiring Bola pada Permainan Sepak Bola

(Studi Korelasional pada Pemain Sepak Bola Mahasiswa Universitas Nusantara PGRI Kediri)

Kediri yang berjumlah 60 orang. Dalam penelitian ini untuk mengambil sampel dari jumlah populasi menggunakan simple random sampling. "Simple random sampling adalah metode penarikan dari sebuah populasi atau semesta dengan cara tertentu sehingga setiap anggota populasi atau semesta tadi memiliki peluang yang sama untuk terpilih atau terambil" (Kerlinger, 2006). Sampel dalam penelitian ini adalah pemain sepak bola mahasiswa Universitas Nusantara PGRI Kediri dengan jumlah 40 orang. Teknik pengumpulan data penelitian ini dilakukan dengan tes dan pengukuran. Untuk memperoleh data koordinasi mata-kaki jenis tes yang digunakan adalah Soccer Dribble Test (Measurement Concepts in Physical Education), data kelincahan dengan tes Dogging Run, data Fleksibilitas Togok dengan tes Sit and Reach (Verducci, 1980), data keseimbangan dinamis dengan tes Modifikasi Bass Tes, data kemampuan menggiring bola dengan tes menggiring bola (Fenanlampir \& Faruq, 2015,. Analisis data yang digunakan dalam penelitian ini adalah analisis regresi dengan studi korelasi (Yulingga \& Himawanto, 2017). Pengujian hipotesis dilakukan dengan taraf signifikasi $\alpha=0.05$.

\section{HASIL DAN PEMBAHASAN}

\section{Hasil}

Penelitian ini merupakan penelitian korelasional, dimana teknik analisis data yang digunakan adalah analisis regresi linear berganda. Hasil analisis regresi linear berganda dapat disajikan pada tabel 1 sebagai berikut:

Tabel 1 Hasil Pengujian Regresi Linear Berganda

\begin{tabular}{lcccc}
\hline Varibel independen & Koefisien & thitung & $\begin{array}{c}\text { Signifikansi } \\
\text { thitung }\end{array}$ & Keterangan \\
\hline Konstanta & 10,055 & & & \\
\hline $\begin{array}{l}\text { Koordinasi Mata- } \\
\text { Kaki }\end{array}$ & 0,295 & 5,472 & 0,000 & Signifikan \\
\hline Kelincahan & 0,268 & 2,716 & 0,010 & Signifikan \\
\hline $\begin{array}{l}\text { Keseimbangan } \\
\text { Dinamis }\end{array}$ & $-0,049$ & $-3,046$ & 0,004 & Signifikan \\
\hline Fleksibilitas togok & $-0,058$ & $-2,595$ & 0,014 & Signifikan \\
\hline
\end{tabular}


Andika Priya Pratama, Sugiyanto Sugiyanto, Agus Kristiyanto

Sumbangan Koordinasi Mata-Kaki, Kelincahan, Keseimbangan Dinamis dan Fleksibilitas Togok

Terhadap Kemampuan Menggiring Bola pada Permainan Sepak Bola

(Studi Korelasional pada Pemain Sepak Bola Mahasiswa Universitas Nusantara PGRI Kediri)

Variabel dependen $=$ Kemampuan menggiring bola

$\mathrm{F}$ hitung $=201,831$

Sig $=0.000$

$\mathrm{R}=0,979$

$R^{2}=0,958$

Std error $=0,28991$

Sementara pembahasan sumbangan masing-masing variable bebas terhadap variable terikat adalah sebagai berikut:

\section{Sumbangan Variabel $X_{1}$ (Koordinasi Mata-Kaki) dengan Variabel $Y$} (Kemampuan menggiring bola).

Nilai koefisien regresi variabel koordinasi mata-kaki $\left(X_{1}\right)$ sebesar 0,295 . Hal ini mengandung arti bahwa setiap kenaikan variabel koordinasi mata-kaki $\left(X_{1}\right)$ mengalami kenaikan satu satuan, maka variabel kemampuan menggiring bola $(\mathrm{Y})$ akan naik sebesar 0,295 dengan asumsi bahwa variabel bebas yang lain dari model regresi adalah tetap. Pada hasil penelitian menunjukkan variabel koordinasi mata-kaki memberikan sumbangan efektif sebesar 29,5\%. Hal ini menjelaskan koordinasi matakaki mempunyai peran penting terhadap kemampuan menggiring bola.

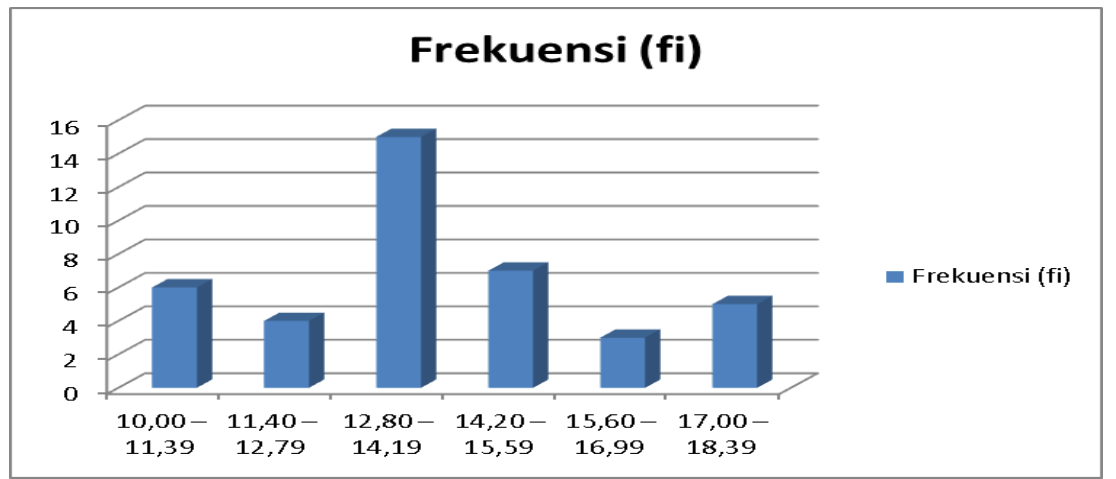

Gambar 1. Frekuensi Variabel Koordinasi Mata-Kaki

\section{Sumbangan Variabel $X_{2}$ (Kelincahan) dengan Variabel $Y$ (Kemampuan menggiring bola).}

Nilai koefisien regresi variabel kelincahan $\left(X_{2}\right)$ sebesar 0,268 . Hal ini mengandung arti bahwa setiap kenaikan variabel kelincahan $\left(X_{2}\right)$ mengalami kenaikan satu satuan, maka variabel kemampuan menggiring bola $(Y)$ akan naik sebesar 0,268 dengan asumsi bahwa variabel bebas 
Andika Priya Pratama, Sugiyanto Sugiyanto, Agus Kristiyanto

Sumbangan Koordinasi Mata-Kaki, Kelincahan, Keseimbangan Dinamis dan Fleksibilitas Togok

Terhadap Kemampuan Menggiring Bola pada Permainan Sepak Bola

(Studi Korelasional pada Pemain Sepak Bola Mahasiswa Universitas Nusantara PGRI Kediri)

yang lain dari model regresi adalah tetap.

Sumbangan efektif variabel kecepatan maksimum terhadap variabel kemampuan menggiring bola sebesar $26,8 \%$. Hal ini membuktikan kelincahan merupakan komponen penting yang berpengaruh terhadap kemampuan menggiring bola.

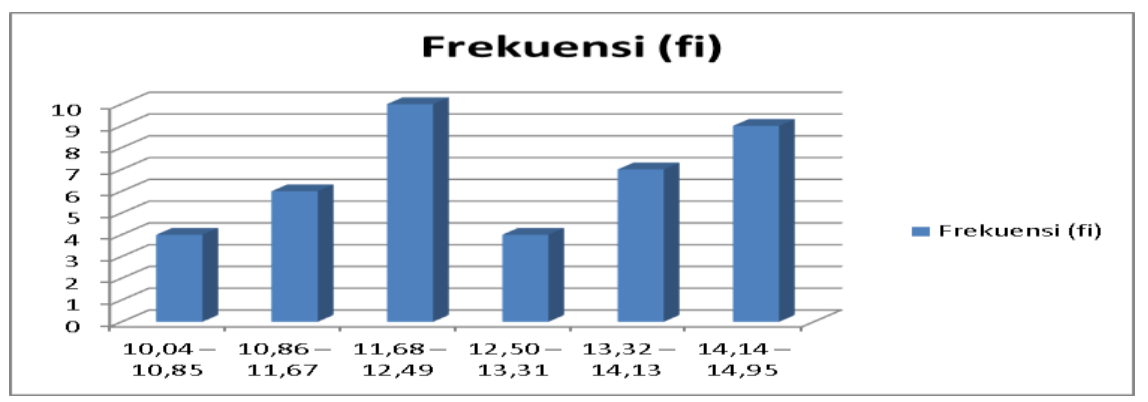

Gambar 2 Frekuensi Variabel Kelincahan

\section{Sumbangan Variabel $X_{3}$ (Keseimbangan Dinamis) dengan Variabel $Y$ (Kemampuan Menggiring Bola).}

Nilai koefisien regresi variabel keseimbangan dinamis $\left(X_{3}\right)$ sebesar 0,049 dan bertanda negatif, ini menunjukan bahwa keseimbangan dinamis $\left(X_{3}\right)$ mempunyai hubungan yang berlawanan arah dengan Risiko Sistemasis. Hal ini mengandung arti bahwa setiap kenaikan variabel keseimbangan dinamis $\left(X_{3}\right)$ mengalami kenaikan satu satuan, maka variabel kemampuan menggiring bola $(Y)$ akan turun sebesar 0,049 dengan asumsi bahwa variabel bebas yang lain dari model regresi adalah tetap. Variabel ini memberikan sumbangan efektif sebesar $4,8 \%$.

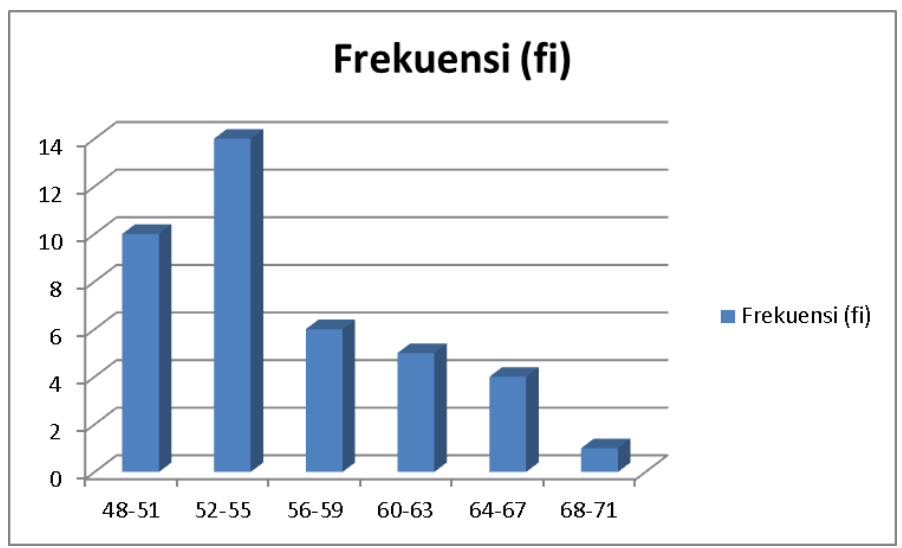

Gambar 3 Frekuensi Variabel Keseimbangan Dinamis 
Andika Priya Pratama, Sugiyanto Sugiyanto, Agus Kristiyanto

Sumbangan Koordinasi Mata-Kaki, Kelincahan, Keseimbangan Dinamis dan Fleksibilitas Togok Terhadap Kemampuan Menggiring Bola pada Permainan Sepak Bola

(Studi Korelasional pada Pemain Sepak Bola Mahasiswa Universitas Nusantara PGRI Kediri)

\section{Sumbangan Variabel $X_{4}$ (Fleksibilitas Togok) dengan Variabel $Y$} (Kemampuan Menggiring Bola).

Nilai koefisien regresi variabel fleksibilitas togok $\left(\mathrm{X}_{4}\right)$ sebesar 0,058 dan bertanda negatif, ini menunjukan bahwa fleksibilitas togok $\left(\mathrm{X}_{4}\right)$ mempunyai hubungan yang berlawanan arah dengan Risiko Sistemasis. Hal ini mengandung arti bahwa setiap kenaikan variabel fleksibilitas togok $\left(\mathrm{X}_{4}\right)$ mengalami kenaikan satu satuan, maka variabel kemampuan menggiring bola $(\mathrm{Y})$ akan turun sebesar 0,058 dengan asumsi bahwa variabel bebas yang lain dari model regresi adalah tetap.

Fleksibilitas togok memberikan sumbangan efektif terhadap kemampuan menggiring bola sebesar 5,8 \%. Hal ini menunjukkan betapa pentingnya fleksibilitas togok dalam meningkatkan kemampuan menggiring bola.

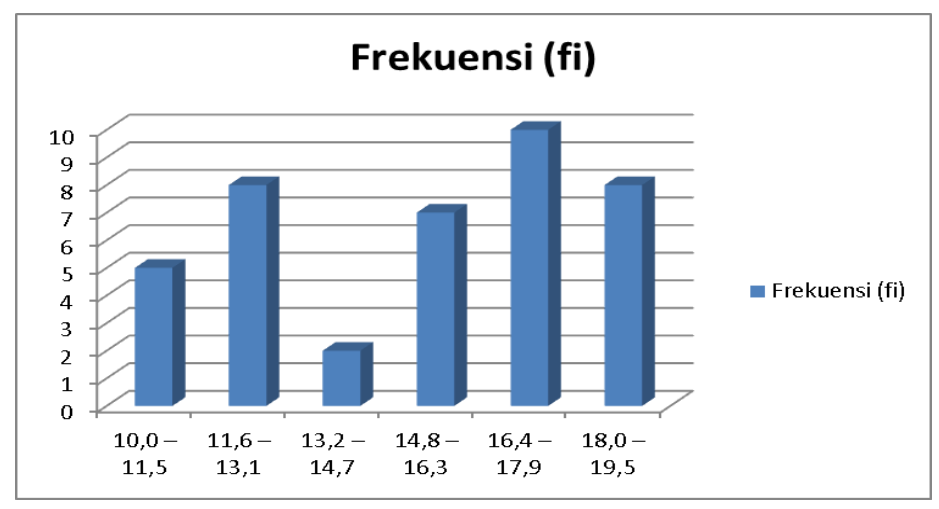

Gambar 4 Frekuensi Variabel Fleksibilitas Togok

5. Sumbangan Secara Bersama-sama (Koordinasi Mata-Kaki, Kelincahan, Keseimbangan Dinamis, Fleksibilitas Togok) Terhadap Kemampuan Menggiring Bola.

Hasil perhitungan $F$ statistik diperoleh nilai $F_{\text {hitung }}$ sebesar 201,831, sedangkan $F_{\text {tabel }}$ sebesar 2,61, karena $F_{\text {hitung }}(201,831)>F_{\text {tabel }}(2,61)$ maka Ho ditolak, artinya variabel independen (koordinasi mata-kaki, kelincahan, keseimbangan dinamis dan fleksibilitas togok) secara bersama-sama (keseluruhan) berpengaruh terhadap variabel dependen 
Andika Priya Pratama, Sugiyanto Sugiyanto, Agus Kristiyanto

Sumbangan Koordinasi Mata-Kaki, Kelincahan, Keseimbangan Dinamis dan Fleksibilitas Togok

Terhadap Kemampuan Menggiring Bola pada Permainan Sepak Bola

(Studi Korelasional pada Pemain Sepak Bola Mahasiswa Universitas Nusantara PGRI Kediri)

(kemampuan menggiring bola).

Tabel 2 Besar Sumbangan Relatif dan Efektif

\begin{tabular}{lcc}
\hline \multicolumn{1}{c}{ Variabel } & $\begin{array}{c}\text { Sumbangan Relatif } \\
(\mathrm{SR})\end{array}$ & $\begin{array}{c}\text { Sumbangan } \\
\text { Efektif }(\mathrm{SE})\end{array}$ \\
\hline Variabel kelincahan $\left(\mathrm{X}_{2}\right)$ & $9,9 \%$ & $26,8 \%$ \\
Variabel koordinasi mata-kaki $\left(\mathrm{X}_{1}\right)$ & $5,4 \%$ & $29,5 \%$ \\
Variabel fleksibilitas togok $\left(\mathrm{X}_{4}\right)$ & $2,2 \%$ & $5,8 \%$ \\
Variabel keseimbangan dinamis $\left(\mathrm{X}_{3}\right)$ & $1,6 \%$ & $4,8 \%$ \\
\hline
\end{tabular}

\section{Pembahasan}

Penelitian ini bertujuan untuk mengetahui seberapa berartinya sumbangan baik masing-masing maupun secara simultan dari variabel bebas (koordinasi mata-kaki, kelincahan, keseimbangan dinamis dan fleksibilitas togok) terhadap kemampuan menggiring bola. Berdasarkan hasil penelitian, terkait pengujian hipotesis perlu dikaji secara mendalam dengan memberikan interpretasi keterkaitan antara hasil analisis yang diperoleh dengan teori yang mendasari penelitian ini. Hal ini dimaksudakn supaya dapat diketahui kesesuaian teori yang telah dipaparkan dengan hasil penelitian yang diperoleh.

Koordinasi mata-kaki memiliki sumbangan efektif sebesar $29,5 \%$. Jika hasil analisis ini dikaitkan dengan teori, maka pada dasarnya hasil penelitian ini mendukung dan memperkuat teori yang sudah ada. Kemampuan mengkoordinasi antara mata dengan kaki, menghasilkan gerakan automatisasi tanpa jeda untuk berpikir mau diolah seperti apa bola yang sedang dikuasai. Kemampuan koordinasi mata-kaki yang dimiliki seorang atlet, mendukung durasi penguasaan bola. Semakin baik koordinasi yang dimiliki, maka lawan akan kesulitan untuk merebut bola.

Analisis statistik juga menunjukkan bahwa kelincahan memiliki sumbangan yang berarti terhadap kemampuan menggiring bola dalam permainan sepak bola. Pada dasarnya, hal ini sebagai bukti bahwa penelitian yang dilakukan memberikan hasil yang dapat mendukung teori yang telah ada. Indikator kelincahan ditunjukkan oleh seorang pemain 
Andika Priya Pratama, Sugiyanto Sugiyanto, Agus Kristiyanto

Sumbangan Koordinasi Mata-Kaki, Kelincahan, Keseimbangan Dinamis dan Fleksibilitas Togok

Terhadap Kemampuan Menggiring Bola pada Permainan Sepak Bola

(Studi Korelasional pada Pemain Sepak Bola Mahasiswa Universitas Nusantara PGRI Kediri)

yang mampu mengubah arah secara cepat tanpa kehilangan keseimbangan. Dalam situasi pertandingan, seringkali pemain dituntut untuk menghindari hadangan lawan dengan melewatinya secara cepat bahkan merubah arah secara cepat. Jika kecepatan merubah arah tidak disertai keseimbangan yang baik, maka dapat dipastikan bola yang dikuasai akan direbut oleh lawan. Hal ini menunjukkan bahwa keseimbangan juga memiliki sumbangan yang berarti terhadap kemampuan menggiring bola dalam permainan sepak bola. Dari analisis statistik, keseimbangan dinamis memberikan sumbangan efektif sebesar $4,8 \%$. Meskipun prosentase sumbangan efektif yang dihasilkan oleh keseimbangan dinamis masih terpaut jauh daripada koordinasi mata-kaki dan kelincahan, namun keseimbangan dinamis merupakan bagian penting dalam pencapaian kemampuan menggiring bola yang baik dan benar. Hal ini diperkuat oleh Khuddus (2017) menyatakan," Sedangkan kelincahan seorang pemain sepak bola untuk bergerak cepat dan merubah arah dan posisi secara tepat membutuhkan keseimbangan tubuh dan keterampilan yang tinggi”.

Selain keseimbangan dinamis, kelincahan juga memiliki unsur pendukung yang lain, yaitu fleksibilitas togok. Kemampuan melewati hadangan lawan, merubah arah secara cepat, akan terlihat sempurna manakala keseimbangan dalam merubah arah didukung oleh kelentukan (fleksibilitas) togok. Fleksibilitas togok memberikan seorang atlet keluwesan maupun gerak elastis pada saat menggiring bola dalam permainan sepka bola. Dengan demikian untuk mendapatkan keterampilan yang baik, maka diperlukan fleksibilitas togok yang baik pula.

Secara bersama-sama (simultan), koordinasi mata-kaki, kelincahan, fleksibilitas togok dan keseimbangan dinamis memberikan sumbangan yang berarti terhadap kemampuan menggiring bola dalam permainan sepak bola. Dari hasil analisis statistik menunjukkan nilai $F_{\text {hitung }}$ sebesar 201,831, sedangkan $F_{\text {tabel }}$ sebesar 2,61 , karena $F_{\text {hitung }}$ 
Andika Priya Pratama, Sugiyanto Sugiyanto, Agus Kristiyanto

Sumbangan Koordinasi Mata-Kaki, Kelincahan, Keseimbangan Dinamis dan Fleksibilitas Togok Terhadap Kemampuan Menggiring Bola pada Permainan Sepak Bola

(Studi Korelasional pada Pemain Sepak Bola Mahasiswa Universitas Nusantara PGRI Kediri)

$>F_{\text {tabel }}(2,61)$ maka Ho ditolak, artinya variabel independen (koordinasi mata-kaki, kelincahan, keseimbangan dinamis dan fleksibilitas togok) secara bersama-sama (keseluruhan) berpengaruh terhadap variabel dependen (kemampuan menggiring bola). Semua komponen baik itu koordinasi mata-kaki, kelincahan, fleksibilitas togok maupun keseimbangan dinamis, mempengaruhi sukses tidaknya seorang atlet dalam menguasai bola, terlebih pada kemampuan menggiring bola. Dalam derajat kemampuan yang sama dari ke empat komponen tersebut, akan menghasilkan kemampuan menggiring bola yang baik. Apabila salah satu diantara komponen tersebut memiliki derajat atau tingkat kemampuan yang rendah (misal, kemampuan koordinasi mata-kaki rendah), maka gerakan menggiring bola juga tidak terkoordinasi dengan baik, begitu juga untuk komponen yang lain. Jadi, unsur penunjang agar seseorang dapat menggiring bola dengan baik harus betul-betul dikuasai secara matang.

\section{KESIMPULAN DAN SARAN}

Koordinasi mata-kaki, kelincahan, keseimbangan dinamis dan fleksibilitas togok memberikan sumbangan yang berarti terhadap kemampuan menggiring bola pada permainan sepak bola. Manfaat yang sangat dirasakan adalah bertambahnya wawasan pemain sepakbola khususnya mahasiswa Universitas Nusantara PGRI Kediri. Dengan demikian hasil penelitian ini dapat dijadikan sumber referensi bahwa untuk merekrut pemain sepak bola berbakat, sangat disarankan mengidentifikasi koordinasi mata-kaki, kelincahan, keseimbangan dinamis dan fleksibilitas togok.

\section{DAFTAR PUSTAKA}

Al-Hadiqie, Z. M. (2014). Menjadi Pemain Sepak Bola Profesional. Yogyakarta: Kata Pena.

Diputra, R. (2015). Pengaruh Latihan Three Cone Drill, Four Cone Drill, dan Five Cone Drill terhadap Kelincahan (Agility) dan Kecepatan (Speed). Jurnal SPORTIF , 1 (1), 41-59.

Hanief, Y. N. (2015). PENGARUH GAYA MENGAJAR TERHADAP HASIL BELAJAR LAY UP SHOOT BOLA BASKET DITINJAU DARI 
Andika Priya Pratama, Sugiyanto Sugiyanto, Agus Kristiyanto

Sumbangan Koordinasi Mata-Kaki, Kelincahan, Keseimbangan Dinamis dan Fleksibilitas Togok

Terhadap Kemampuan Menggiring Bola pada Permainan Sepak Bola

(Studi Korelasional pada Pemain Sepak Bola Mahasiswa Universitas Nusantara PGRI Kediri)

KOORDINASI MATA-TANGAN. EFEKTOR (E), 2(2). https://doi.org/10.29407/e.v2i2.69.

Hanief, Y. N., \& Himawanto, W. (2017). Statistik Pendidikan. Yogyakarta: Deepublish.

Hanief, Y. N., Puspodari, P., \& Sugito, S. (2017). Profile of physical condition of Taekwondo Junior Athletes Pusklatkot (Training centre) Kediri city year 2016 to compete in 2017 east java regional Competition. International Journal of Physiology, Nutrition and Physical Education, 2(2), 262-265.

Kerlinger. (2006). Asas-asas Penelitian Behavior. Edisi 3, cetakan 7. Yogyakarta: Gadjah Mada University Press.

Khuddus, L. A. (2017). Gangguan Perilaku Makan dan Tingkat Kecukupan Energi Protein Terhadap Kebugaran Jasmani Pemain Sepak Bola IKOR FIK UNESA. Jurnal SPORTIF: Jurnal Penelitian Pembelajaran, 3(1), 44-54.

Pratama, B. A. (2015). Kontribusi Kecepatan dan Kelentukan Terhadap Hasil Menggiring Bola. Jurnal SPORTIF: Jurnal Penelitian Pembelajaran, 1(1), 74-80.

Sadik, S. (2016). Upaya Meningkatkan Keterampilan Dribble Bola Dalam Permainan Sepak Bola Dengan Metode Student Teams Achievement Division Pada Siswa Kelas IV Dan V SDN Blumbungan 1 Pamekasan Tahun Ajaran 2015-2016. Jurnal SPORTIF : Jurnal Penelitian Pembelajaran, 2(1), 87-92.

Scheunemann, Timo. (2012). Kurikulum Sepak bola Indonesia Untuk Usia Dini (U5-U12), (U13-U20) \& Senior. Jakarta: PSSI.

Sergey, L., Anatoly, A., Boris, B., Svyatoslav, K., \& Victoria, K. (2017). Influence of training loadings on the state program of children's and youth sports schools in Ukraine on psycho-physiological indicators of 10-12-year-old football players. Journal of Physical Education and Sport, 2583-2587.

Tarigan, Beltasar. (2001). Pendekatan Keterampilan Taktis Dalam Pembelajaran Sepak bola. Jakarta: Depdiknas. Direktorat Jenderal Pendidikan Dasar dan Menengah. Bekerjasama Dengan Direktorat Jenderal Olahraga.

Verducci, F. M. (1980). Measurement Concepts in Physical Education. St. Louis: Mosby. 